\title{
PEMANFAATAN TEKNOLOGI UNTUK PEMBELAJARAN JARAK JAUH DI MASA PANDEMI COVID-19
}

\author{
Rizki Aulianita ${ }^{1}$, Albert Riyandi ${ }^{2}$, Agus Wiyatno ${ }^{3}$, Vito Triantori ${ }^{4}$, Numan Musyaffa ${ }^{5}$ \\ Sistem Informasi, Sekolah \\ Tinggi Manajemen Informatika dan Komputer Nusa Mandiri \\ Jl. Jatiwaringin No. 2 Cipinang Melayu, Makasar, Jakarta Timur \\ rizki.rzk@nusamandiri.ac.id ${ }^{1}$, albert.abe@nusamandiri.ac.id ${ }^{2}$, agus.agq@nusamandiri.ac.id ${ }^{3}$, \\ vito.vto@nusamandiri.ac.id ${ }^{4)}$,numan.nmf@nusamandiri.ac.id ${ }^{5)}$
}

\begin{abstract}
The use of technology as a learning medium during the Covid-19 pandemic is an alternative solution to be able to continue to carry out long-distance learning activities. Existing technologies such as Google Meet, Google Classroom and Google Drive strongly support students and teachers and other academics in teaching and learning activities. The use of the facilities provided by Google can be useful for academics. Teaching and learning activities synchronously (synchronous) using video conferencing is an effective way. Not only that, asynchronous learning media using existing Google Classroom facilities such as discussion and chat features are one of the media to support distance learning to keep it running smoothly. The activity was carried out at Majlis Ta'lim Hidayatul Mubtadiin, which consisted of teenagers aged 12-17 years. Based on the questionnaires distributed during the activity, that as many as $96 \%$ were able to absorb the material with this distance learning media. So that learning can still be carried out effectively and conducively in the midst of the Covid-19 pandemic.
\end{abstract}

\section{Keywords: distance learning, Google classroom, learning media}

\begin{abstract}
Abstrak
Penggunaan teknologi sebagai media pembelajaran di masa pandemi Covid-19 ini merupakan salah satu alternatif solusi untuk dapat tetap melakukan kegiatan pembelajaran dengan jarak jauh. Teknologi yang saat ini ada seperti Google Meet, Google Classroom dan Google Drive sangat mendukung para murid dan guru serta akademisi lainnya dalam kegiatan belajar mengajar. Pemanfaatan fasilitas yang disediakan oleh Google ini dapat bermanfaat bagi para akademisi. Kegiatan belajar mengajar secara sinkron (synchronous) dengan menggunakan video conference menjadi salah satu cara yang efektif. Tidak hanya itu, media pembelajaran secara asinkron (asynchronous) dengan menggunakan fasilitas Google Classroom yang ada seperti fitur diskusi dan chat merupakan salah satu media untuk menunjang pembelajaran jarak jauh agar tetap berjalan lancer. Kegiatan dilaksanakan di Majlis Ta'lim Hidayatul Mubtadiin yang beranggotakan para remaja yang berusia 12-17 Tahun. Berdasarkan kuisioner yang disebar saat kegiatan berlangsung, bahwa sebanyak $86 \%$ puas dan mampu menyerap materi dengan media pembelajaran jarak jauh ini. Sehingga belajar tetap dapat terlaksana secara efektif dan kondusif di tengah pandemi Covid-19.
\end{abstract}

Kata kunci: pembelajaran jarak jauh, Google classroom, media belajar

\section{PENDAHULUAN}

Dalam masa pandemi Covid-19 ini, pemerintah menghentikan pembelajaran secara offline dan diganti menjadi pembelajaran jarak jauh yang dilakukan secara daring. Sistem pembelajaran jarak jauh ini merupakan solusi yang tepat di masa pandemik saat ini agar kegiatan belajar mengajar tetap dapat terlaksana dengan baik dan menyelamatkan para peserta didik agar selalu di rumah dan meminimalisir terjadinya penularan virus corona. Penerapan ini dimulai pada bulan Maret 2020. Menteri Pendidikan dan Kebudayaan berupaya agar mutu pendidikan di Indonesia dalam penyelenggaraan system pembelajaran jarak jauh ini tetap terjaga. Sehingga sumber daya yang dihasilkan tetap memnuhi kualitas yang baik. Pembelajaran jarak jauh yaitu pendidikan yang dilaksanakan oleh peserta didik dan pengajar, dalam hal ini memenfaatkan media teknologi sebagai sarana untuk menunjang pembelajaran yang dilakukan secara daring. 
Pembelajaran jarak jauh atau disebut dengan istilah Pendidikan Jarak Jauh (PJJ), bukan saat ini saja penerapannya. Hal ini sudah banyak diterapkan sejak dahulu, yang dilakukan secara terpisah Antara instruktur dan narasumber di luar kelas sehingga tidak terjadi pertemuan tatap muka secara langsung dengan memanfaatkan chatting, berkirim email[1]

Objek dari system pembelajaran jarak jauh ini ada pada peserta didik, guru atau pengajar hanya sebagai fasilitator. Berbeda halnya dengan pembelajaran secara tatap muka langsung, dimana guru bertugas menjelaskan seluruh materi seperti ceramah. Sedangkan dengan PJJ ini, objeknya adalah murid atau peserta didik tersebut. Peserta didik harus aktif dalam pembelajaran, dapat memanfaatkan teknologi seperti forum diskusi grup melalui Whatsapp, dan lainnya

Kecenderungan masyarakat, yang saat ini sudah umum menggunakan telepon pintar (smartphone) dibandingkan computer (PC) menjadi salah satu kemudahan untuk media pembelajaran berbasiskan Teknologi dan Informasi serta Komputer (TIK) sehingga mendorong pelaksanaan pembelajaran jarak jauh. Teknologi seperti Wireless Aplication Protocol (WAP) merupakan salah satu alternative solusi pembelajaran yang menggunakan device secara mobile dengan informasi yang ada di internet sehingga memudahkan user dalam mengakses dan saling berhubungan dengan layanan internet.[2]

Teknologi yang ada saat ini, telah menjadi sebuah trend dalam pemanfaatan pembelejaran jarak jauh seperti Google Classroom. Keuntungan dari implementasi Google classroom adalah lebih mudah digunakan di smartphone ataupun PC. Terciptanya peluang yang sama dalam kegiatan belajar sehingga mendorong mahasiswa untuk tertarik dalam penggunaan Google Classroom dengan fasilitas yang dimilikinya.[3]

Google sebagai salah satu platform yang dapat melihat peluang, bahwasanya kedepan pemanfaatan media secara online sangat digandrungi, khususnya di masa pandemi ini, dengan berbagai fasilitas yang tersedia seperti Google Meet, Google Classroom, Google Drive untuk media penyimpanan secara cloud computing dan Google Kalender sehingga memudahkan pihak peserta didik dan pengajar untuk mencapai terselenggaranya pendidikan secara formal berbasis online dengan menggunakan literasi internet.

Selain keuntungan yang telah dijabarkan diatas, pembelajaran jarak jauh ini memiliki dampak negative, yaitu ssitem pembelajaran yang kurang baik, dalam hal ini adalah materi atau konten yang disediakan oleh guru atau pengajar masih standart. Sehingga mutu kualitas pembelajaran masih kurang, disamping itu tidak semua siswa atau peserta didik dapat memiliki smartphone atau kuota internet untuk dapat mengakses media pembelajaran sehingga kurang efektif dan membebankan para orang tua atau wali murid dalam pembelian kuota internet.

Kemendikbud berujar bahwa pemanfaatan berbagai platform pendidikan yang kini sudah ada harus dikombinasikan dengan model hybrid. Model pembelajaran berbasis kombinasi terbukti berhasil untuk menciptakan SDM yang unggul dan memiliki daya saing tinggi di dunia industry.

Dalam penelitian terdahulu, terkait Penggunaan Google Classroom yaitu menunjukan hasil yang optimal yang dinilai berdasarkan kriteria sebagai berikut: Google Classroom sebagai perencanaan media pembelajaran yang berbasis presentasi atau social, kedua pelaksanaan melalui smarphone, ketiga system penilaiaan secara langsung yang tersedia, Faktor yang mempengaruhi dalam akses ke dalam Google Classroom.[4]

Media teknologi, tidak hanya Google saja untuk dapat menunjang pembelajaran jarak jauh ini, terdapat media yang lain seperti Zoom, Learning Management System (e-learning), WhatsApp sehingga kegiatan belajar dapat terlaksana secara baik dan efektif, tentunya dengan menggunakan koneksi internet.[5]

Selain media pembelajaran di atas, terdapat banyak teknologi yang memberikan kemudahan dalam system pembelajaran jarak jauh yaitu aplikasi Webex, Youtube, Ruang Guru, Zenius dll.

Dalam penelitian ini difokuskan kepada platform Google. Penggunaan fasilitas yang dimiliki oleh Google seperti Google Classroom, Google meet, Google Drive. Dalam penjelasaan di atas, bahwa Google Classroom saat ini menjadi trend dalam media pembelajaran jarak jauh. Selain mudah diakses, fiturnya yang sangat user friendly dan juga dapat menampilkan report bagi perkembangan setiap peserta didik.

Google meet merupakan salah satu pembelajaran yang synkron (synchronous) dimana setiap peserta didik dan guru dapat melihat wajah atau bertatap muka secara virtual sehingga pengajar dapat langsung menjelaskan materi bahan ajar kepada peserta didiknya dengan mudah. Google meet pun memiliki akses yang tidak dibatasi waktunya. Hal ini merupakan salah satu keuntungan yang dimiliki oleh video conference ini.

Sedangkan Google Drive, yaitu media penyimpanan secara cloud computing, yang dapat diakses kapanpun serta dimanapun secara online. Google drive ini memudahkan pengajar untuk mengupload materi dan bahan ajar lain ke dalam Google Classroom, begitupun sebaliknya, siswa 
dapat mengupload tugas ke dalam Google classroom secara mudah dan cepat. Kemudahan yang diberikan ini meminimalisir penyimpanan (storage) secara offline. Sehingga pada saat kita membutuhkan, dapat diakses dengan cepat dan mudah. Diatas, peneliti telah menyebutkan salah satu teknik pembelajaran secara sinkron (synchronous) dan pada pembahasan ini, peneliti akan menjelaskan teknik pembelajaran secara asinkron (asynchronous) yaitu kegiatan yang dilakukan tanpa tatap muka secara virtual, seperti chatting, WAG, Tanya jawab di forum diskusi grup secara online.[6]

\section{METODE PENGABDIAN MASYARAKAT}

Tahapan metode yang digunakan dalam pengabdian masyrakat ini, khususnya untuk peserta didik remaja pada Majlis ta'lim Hidayatul Mubtadiin yaitu:

1. Perncanaan kegiatan

2. Analisa Kebutuhan Penyuluhan

3. Pembuatan dan Pengajuan Proposal

4. Persiapan Modul sebagai bahan ajar

5. Persiapan infrastruktur penyuluhan secara online

6. Pelaksanaan

7. Laporan

Penyuluhan yang diadakan sebagai pengabdian masyarakat oleh dosen STMIK Nusa Mandiri ini, dengan sasaran memberikan media pembelajaran secara daring menggunakan platform Goolge. Dengan objeknya yaitu peserta didik yang berusia remaja Antara 12-17 tahun.

Metode kegiatan penyuluhan ini berupa penyampaian teori secara umum, kemudian langsung praktek dengan menggunakan laptop masing-masing, dengan arahan dari tim tutor yang dilaksanakan secara online. Adapun selama kegiatan penyuluhan berlangsung, panitia serta tim tutor bersinergi dengan tujuan:

1. Setiap siswa paham menggunakan aplikasi yang disediakan seperti Google Classroom, Google meet, Google Drive

2. Memudahkan bagi setiap siswa yang terlibat sehingga dapat diimplementasikan untuk pembelajaran jarak jauh yang saat ini sedang dijalani.

3. Diharapkan kedepannya, siswa dapat menyebarluaskan informasi dan kegiatan pengabdian masyrakat ini melalui blog, kanal Youtube ataupun wordpress sehingga dapat bermanfaat.

4. Teknologi yang disediakan oleh Google dan platform lainnya, diharapkan setiap siswa tidak gaptek dalam menerapkan teknologi tersebut, khususnya untuk media pembelajaran jarak jauh.

\section{HASIL DAN PEMBAHASAN}

\section{Materi pelatihan}

Cakupan materi yang disampaikan adalah:

1. Pengenalan awal tentang Google, fasilitas yang ada di Google.

2. Mengikuti langkah-langkah dalam membuat Google Classroom dan cara menjadi siswa untuk masuk ke dalam Google Classroom

3. Menggunakan Google meet sebagai media video conference untuk berkomunikasi secara tatap muka virtual (synchronous), mengulik fitur yang ada dan cara membuat jadwal meeting secara langsung atau terencana menggunakan Google calendar

4. Cara penggunaan media penyimpanan secara cloud computing dengan memanfaatkan fasilitas Google Drive, menjelaskan menu-meu yang tersedia di Google drive, cara upload dokumen dan membagikan url untuk dokumen tersebut.

5. Membuat blog, dengan kontennya berisi penggunaan Google platform yang terdiri dari Google classroom, Google meet, gole drive sebagai media pembalajaran jarak jauh.

\section{Instrumen pelaksanaan}

Dalam pelaksanaan program pelatihan ini dibutuhkan para pengajar, modul ajar, sarana komputer atau laptop, LCD (Proyektor) dan juga fasilitas video conference yang sudah terinstall di dalam komputer. Interumen pelaksanaan tersebut harus saling berkesinambungan demi terciptanya penyuluhan yang baik dan memiliki target yang tepat sasaran.

Dalam pelaksanaan penyuluhan yang dilakukan secara daring menggunakan video conference ini berupaya semaksimal mungkin agar narasumber atau Tutor dapat menyampaikan materi secara baik sesuai dengan modul dan Tim Tutor juga dapat menjawab pertanyaan yang diajukan oleh siswa melalui fitur chatting jika ada permasalahan yang ditemukan.

Pada dasarnya, penyuluhan dilaksanakan seacara daring ini bertujuan untuk menekan laju penyebaran Covid-19, sehingga instrument pelaksanaan dan modul sudah harus dipastikan ada dan terinstall di laptop masing-masing siswa sehingga meminimalisir adanya kendala di lapangan.

\section{Pelaksanaan Kegiatan}

Pengabdian Masyarakat ini berupa penyuluhan dilaksanakan di tempat majlis ta'lim 
P-ISSN: 2774-5007 | E-ISSN: 2774-499X

Vol. 2 No. 2 Oktober 2020 | Hal. 37-44

Diterima Redaksi : 01-10-2020 | Selesai Revisi : 22-10-2020 |

Diterbitkan Online : 23-10-2020

Hidayatul Mubtadiin yang dilaksanakan secara online pada tanggal 13 September 2020 dengan mengikutsertakan remaja yang berusia 12-17 tahun. Dosen atau tim tutor memberikan materi secara daring melalui video conference, melakukan Tanya jawab serta berinteraksi secara virtual. Majlis Talim tersebut berlokasi di Gg. H. Ripuh RT 01/ RW 011 No. 22 Paninggilan Utara- Kota Tangerang. Mengingat masih harus terjaganya kesehatan dalam masa pandemic Covid-19 ini maka kami akan mengajarkan kepada peserta Pengabdian Masyarakat kali ini, Bagaimana Pembelajaran Jarak Jauh dengan menggunakan aplikasi Google Classroom dan aplikasi Google meet untuk pembelajaran jarak jauh, baik dalam acara keagamaan seperti pengajian anak-anak dan remaja Majelis Ta'lim Hidayatul Mubtadin ataupun untuk kepentingan belajar secara formal.
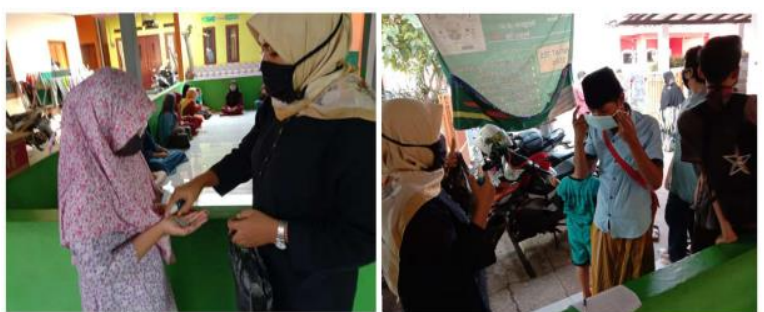

Gambar 1. Tatacara protocol kesehatan

Foto yang ditunjukkan pada gambar 1 merupakan standar protokol kesehatan yang dilakukan sebelum kegiatan dimulai. Setiap peserta wajib menggunakan masker, dicek suhu badan serta menjaga jarak atau melakukan social distancing selama kegiatan berlangsung. Bagi yang memiliki gejala seperti bersin-bersin, batuk ataupun demam tinggi tidak diperkenankan mengikuti kegiatan penyuluhan tersebut.

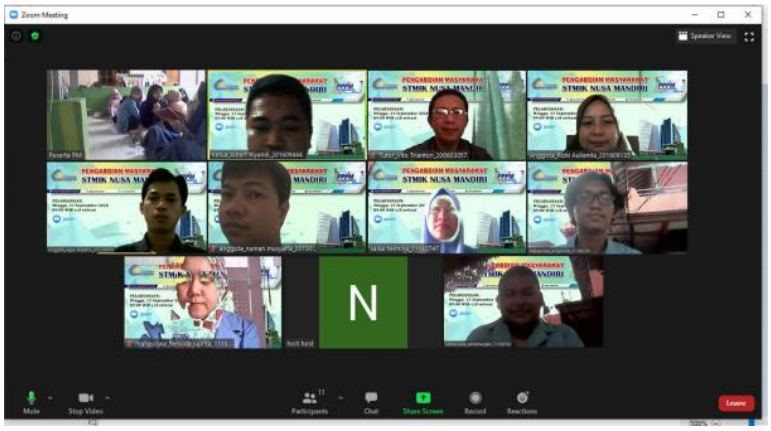

Gambar 2. Video Conference dengan dosen dan Tim Tutor

Gambar 2 adalah proses pelaksanaan yang dilakukan secara virtual menggunakan video conference. Adapun video conference yang digunakan menggunakan aplikasi zoom meeting. Kami para dosen juga melibatkan beberapa orang
ABDIMAS NUSA MANDIRI

JURNAL PENGABDIAN KEPADA MASYARAKAT NUSA MANDIRI

mahasiswa untuk terjun langsung dalam acara kegiatan pengabdian masyarakat ini. Agar mereke dapat terlibat dan mengetahui secara detail tentang kondisi yang ada di lapangan.

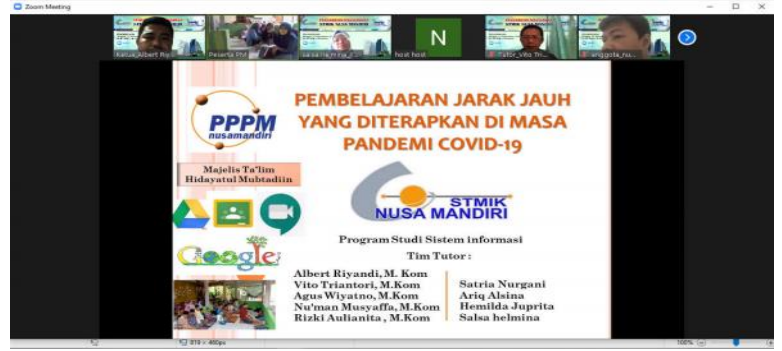

Gambar 3. Materi yang disampaikan

Pada Gambar 3 materi yang disampaikan sesuai dengan kondisi pembelajaran yang terjadi saat ini yaitu pembelajaran jarak jauh sebagai materi penyuluhan. Agar dirasakan manfaatnya oleh para peserta didik dan guru yang ada di majlis talim tersebut. Pembelajaran jarak jauh ini, menggunakan aplikasi yang disediakan oleh Google seperti Google Meet, Google Classroom dan Google Drive. Tim Tutor dan para mahasiswa juga panitia pengabdian masyarakat berkontribusi agar kegiatan ini dapat berjalan secara optimal.

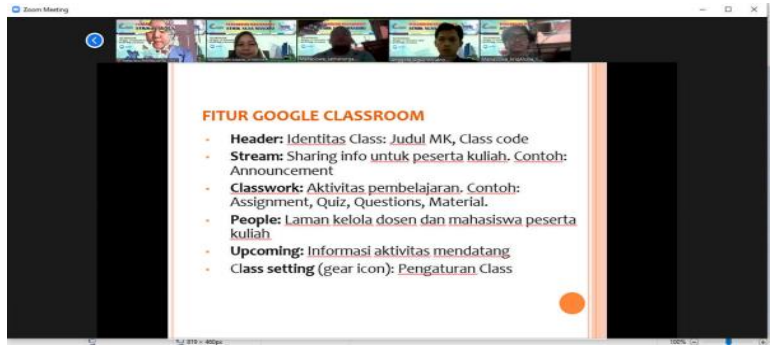

Gambar 4. Penjelasan Materi Pembelajaran

Pada gambar 4 terlihat slide yang menjelasan mengenai fitur Google classroom yang tersedia. Penjelasan ini diberikan oleh Tim Tutor secara bergantian dan jika ada yang tidak dipahami atau dimengerti, maka peserta dapat mengklik fitur raise hand untuk bertanya ataupun via chatting dengan menunjukan hasilnya pada screen meeting kemudian dosen memberikan solusinya.

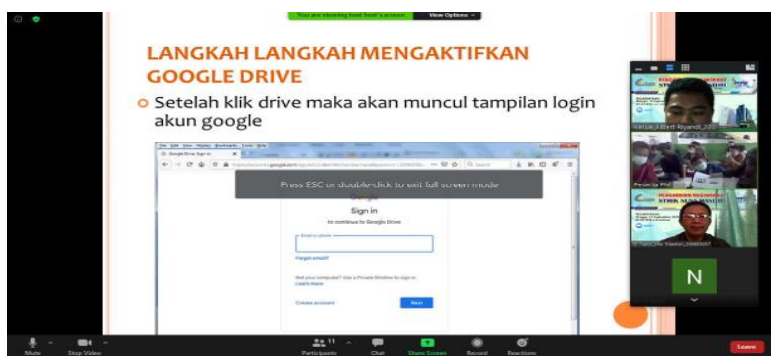

Gambar 5. Materi mengenai Google Drive 
Gambar 5 menjelaskan bahwa peserta atau siswa juga diberikan cara untuk dapat mengakses Google drive dan melakukan upload menggunakan media tersebut. Ada beberapa yang sudah mengetahui fitur ini, namun kebanyakan peserta didik belum pernah mengetahui dan menggunakan Google drive tersebut.
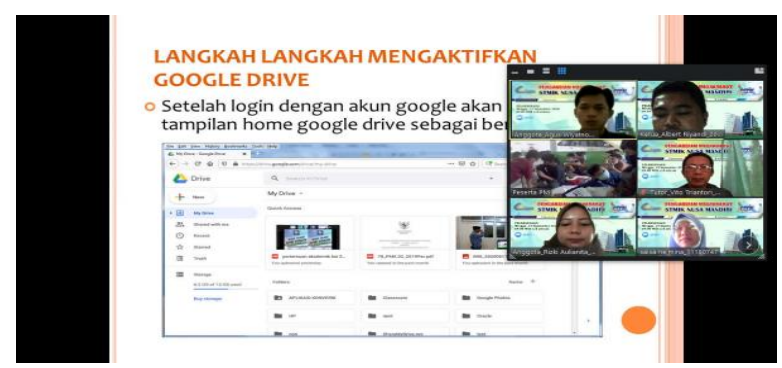

Gambar 6. Cara Mengaktifkan Google Drive

Pada gambar 6, dijelaskan langkah-langkah dalam mengaktifkan Google drive, mulai dari step awal login hingga dokumen berhasil diupload. Pada proses itu, dijelaskan pula menu yang tersedia di gdrive serta cara penggunaannya.

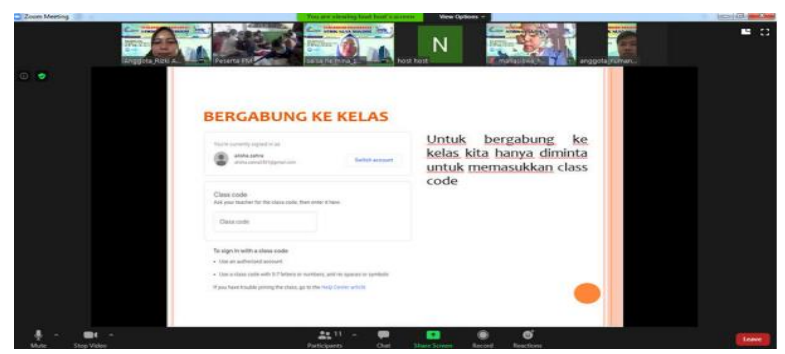

Gambar 7. Penjelasan Google Classroom
Penjelasan Google classroom sangat bermanfaat sekali sebagai media yang mereka gunakan seharihari di sekolah selama masa pandemi ini. Fitur yang sangat bagus, tampilan yang user friendly membuat Google classroom banyak digunakan oleh para guru dan murid di sekolah formal. Sehingga sebagian peserta didik, sudah banyak yang mengetahui tentang informasi ini.

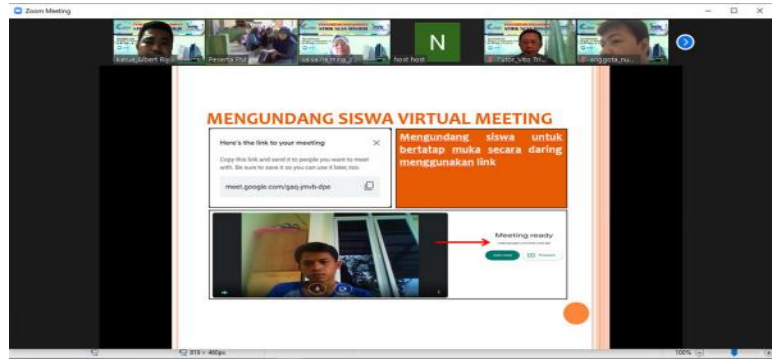

Gambar 8. Penjelasan materi lanjutan

Gambar 8 adalah salah satu bukti penjelasan mengenai penggunaan Google meeting sebagai salah satu media pembelajaran melalui video conference. Siswa juga diberikan informasi cara membuat video conference, share materi melalui screen dan membagikan link untuk mengundang teman supaya dapat bergabung dalam video conference yang sama.

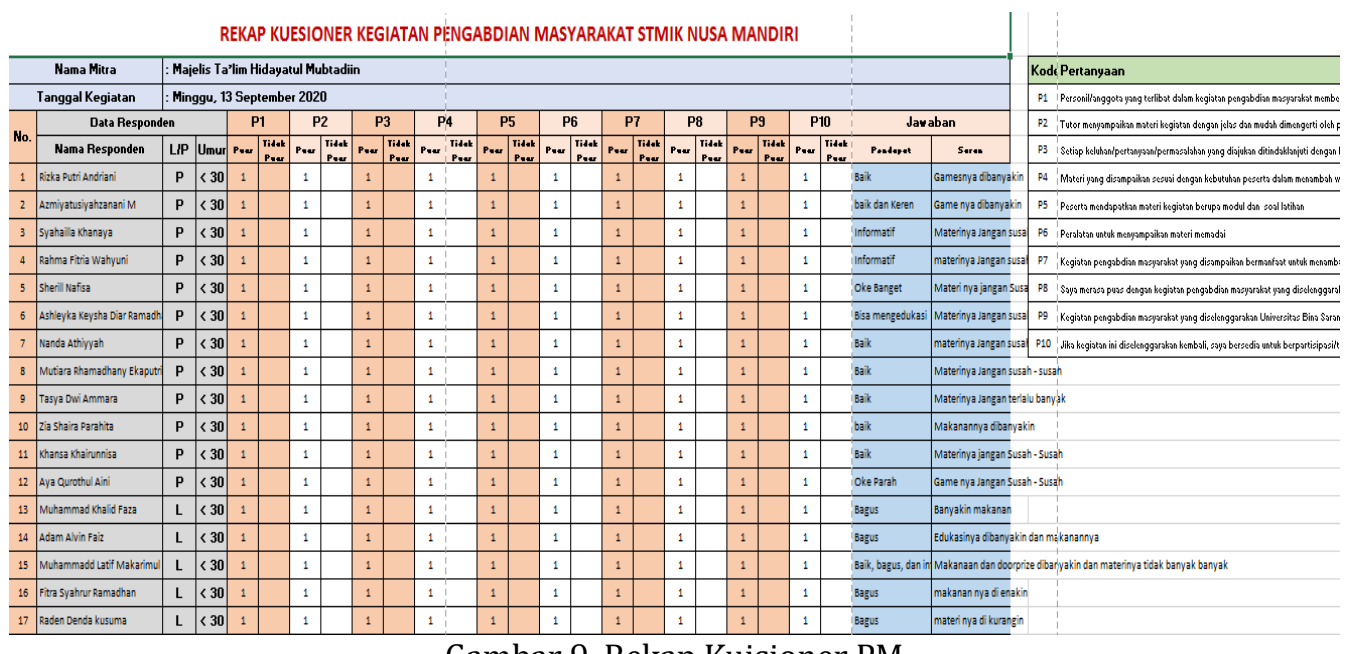

Gambar 9. Rekap Kuisioner PM

Pada Gambar 9, merupakan rekap kuisioner PM yang telah diambil sampelnya saat acara berlangsung. Responden yang terlibat sebanyak 28 orang dengan usia $<20$ Tahun serta berjenis kelamin laki-laki dan perempuan. Kuisioner yang dibagikan tersebut untuk penilaiaan rangkaian 
acara kegiatan dengan point penilaian yaitu kepuasan peserta dalam pelayanan pengabdian masyarakat yang dilakukan, kemudian sebarapa efektif materi yang disajikan dapat bermanfaat bagi setiap peserta, cara tutor dalam penyampaian materi, materi yang disampaikan sesuai dengan kebutuhan peserta atau tidak, peralatan untuk PM sudah memadai atau belum.

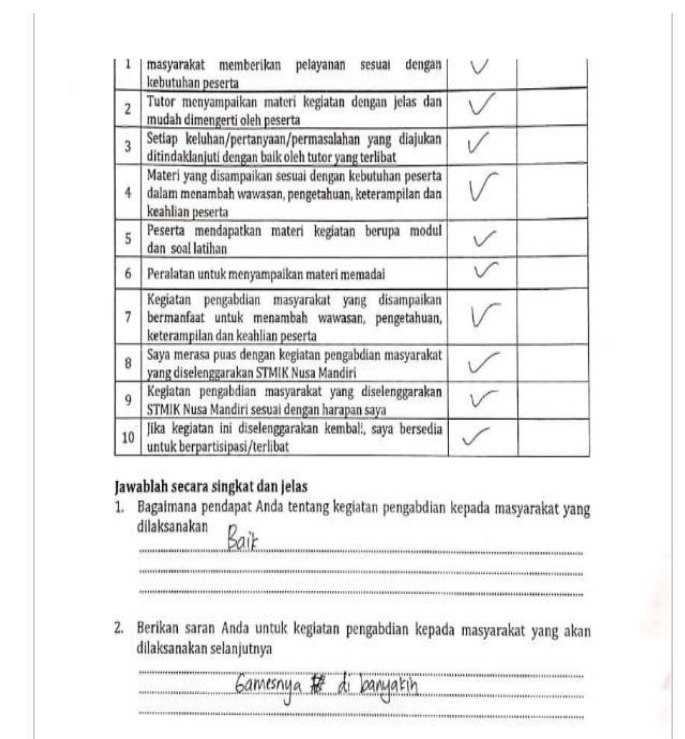

Gambar 10. Kuisioner Pengabdian Masyarakat

Pada kegiatan pengabdian masyarakat tersebut diberikan kuisioner di sesi akhir acara yang dapat dilihat pada gambar 10. Kuisioner tersebut dibuat bertujuan untuk melihat apakah kegiatan PM berjalan sesuai dengan rencana dan tepat sasaran atau tidak, dan dapat melihat manfaat dari kegiatan pengabdian masyarakat tersebut.

\section{KESIMPULAN}

Berdasarkan kegiatan yang telah dilaksanakan pada pengabdian masyarakat periode ganjil 2020/2021 dihasilkan kesimpulan bahwa sebanyak $86 \%$ merasa puas dan mampu menyerap materi yang diberikan mengenai teknologi pembelajaran untuk jarak jauh. Sedangkan sisanya sebesar 14\% merasa ada kendala dalam hal internet dan kuota yang dimiliki sehingga tidak bisa mengakses pembelajaran jarak jauh. Kegiatan ini diikuti oleh 28 orang peserta yang terdiri dari jenis kelamin laki-laki dan perempuan serta 5 Orang Tim Tutor dan 4 orang mahasiswa yang terlibat.

\section{SARAN}

Saran untuk kegiatan pengabdian masyarakat ini yaitu diharapkan kedepannya dapat menjalin kerja sama yang baik antara pihak STMIK Nusa Mandiri dengan Majlis ta'lim dengan membuatkan MOU. Untuk di semester yang akan datang diharapkan kegiatan tri dharma ini, tepatnya pengabdian masyarakat dapat terselenggara secara routin dan berkelanjutan sehingga dapat dilihat feedback dari penyelenggaraan penyuluhan ini sehingga manfaatnya dapat dirasakan oleh peserta.

\section{UCAPAN TERIMA KASIH}

Terimakasih kepada semua pihak yang telah mendukung:

1. Pimpinan Majlis ta'lim Hidayatul Mubtadiin.

2. Ketua Majlis Ta'lim Ibu Ustadzah Dian Kurniasih

3. Ketua STMIK Nusa Mandiri

4. Prodi SI STMIK Nusa Mandiri

5. Ka PPPM STMIK Nusa Mandiri

6. Dan pihak-pihak yang tidak dapat disebutkan satu-persatu

\section{DAFTAR REFRENSI}

[1] J. W. Kusuma and H. Hamidah, "Perbandingan Hasil Belajar Matematika Dengan Penggunaan Platform Whatsapp Group Dan Webinar Zoom Dalam Pembelajaran Jarak Jauh Pada Masa Pandemik Covid 19," JIPMat, vol. 5, no. 1, 2020.

[2] B. E. Purnama, "Pemanfaatan Teknologi WAP Telepon Seluler Untuk Media Pembelajaran Jarak Jauh," vol. 1, no. 3, pp. 22-28, 2009.

[3] S. A. Hapsari and H. Pamungkas, "Pemanfaatan Google Classroom Sebagai Media Pembelajaran Online Di Universitas Dian Nuswantoro," WACANA J. Ilm. Ilmu Komun., vol. 18, no. 2, pp. 225-233, 2019.

[4] Syaefulloh, "Implementasi Penggunaan Google Classroom Sebagai Implementation of the Use of Google Classroom As a Support for," pp. 36-40.

[5] R. Pakpahan and Y. Fitriani, "JISAMAR (Journal of Information System, Applied, Management, Accounting and Researh)," vol. 4, no. 2, pp. 30-36, 2020.

[6] F. A. Wahyuni, "Blended Learning: Dua Metode ( Synchronous and Asynchronous ) Untuk Matakuliah Writing Materi Argumentative Essay," Jinotep, vol. 3, no. 137, pp. 137-143, 2017. 